\title{
Yaşlı Bireylerin ve Onlara Bakım Veren Akrabalarının İletişim Becerilerinin İncelenmesi: Konya İli Örneği
}

\author{
DOI: $10.26466 /$ opus.713738
}

\author{
Seher Ersoy Quadir* - Gülay Temiz ${ }^{* *}$ \\ * Doç. Dr., Necmettin Erbakan Üniversitesi Sağlık Bilimleri Fakültesi, Konya/Türkiye \\ E-Posta: seherers@gmail.com ORCID: $\quad \underline{0000-0001-7492-5100}$ \\ ** Dr. Öğretim Üyesi, Selçuk Üniversitesi Sağlık Bilimleri Fakültesi, Konya/Türkiye \\ E-Posta: gtemiz@selcuk.edu.tr ORCID: 0000-0002-8428-8966
}

\section{Öz}

Iletişim becerileri, sözel olan ve olmayan mesajlara duyarlılı, etkili olarak dinleme ve etkili olarak tepki verme davranışlarıdır (Korkut, 2005: s.143). Bu araştırma, yaşl bireyle ona bakım veren akrabalarının iletişim becerisi düzeylerini demografik özelliklerine bağh olarak iletişim bilimleri ve sosyal hizmet bağlamında incelemek amacıyla yürütülmüştür. Araştırmanın örneklemini 2017 yılında Konya il merkezinde yer alan üç ilçede (Meram, Selçuklu ve Karatay) ikamet eden 60 ve üzeri yaşlarındaki yaşlılar evreninden tesadüfi örneklem yöntemi ile seçilen 115 birey ve onların bakımın üstlenen 115 akrabası oluşturmuştur. Araştırmaya katılan yaşlı bireylerin ve onlara bakım veren akrabalarının iletişim becerilerine yeterli düzeyde sahip oldukları gözlenmiştir. Bununla birlikte yaşlısına bakım verenlerin iletişim becerilerinin, yaşlı bireylere göre daha fazla olduğu saptanmıştır ( $p<0.001)$. Ayrıca örneklemi oluşturan bireyler arasında kadınların $(p<0.01)$, yaşça küçük olanların $(p<0.001)$, eğitim düzeyi yüksek olanların ( $p<0.001)$, ve sosyal güvencesi Emekli Sandiğg olanların $(p<0.05)$ iletişim becerilerinin daha fazla olduğu görülmüştür. Genel olarak araştırma bulgularında, eğitimin bireylerin iletişim becerisiyle oldukça ilişkili olduğu saptanmıştır. Sonuç olarak bireylerin iletişim becerilerinin geliştirilmesine yönelik örgün ve yaygın eğitim programlarının gerekliliği vurgulanmıştır.

Anahtar Kelimeler: Yaşlı birey, bakım verici akrabalar, iletişim becerisi 
ISSN:2528-9527

E-ISSN : 2528-9535

YIl Year: 11

Cilt Volume: 17

Sayı Issue :38

Uluslararası Toplum Araştırmaları Dergisi

International Journal of Society Researches

Haziran June 2021

Makalenin Geliş Tarihi Received Date: 02/04/2020

Makalenin Kabul Tarihi Accepted Date: 15/03/2021

\title{
An Investigation of Communication Skills of Elderly Individuals and Their Caregiver Relatives
}

\begin{abstract}
Communication skills are sensitivity to verbal and non-verbal messages, effective listening and responsive behaviors (Korkut, 2005: p.143). This study has been conducted for the purpose of determining about elderly individuals' and their caregiver relatives' communication skills depending on their level of demographic characteristics in the context of communication science and social work. The sample group of the study consists of 115 elderly individuals about 60 or more years old and 115 their caregiver relatives were selected randomly in three municipality centres (Meram, Selçuklu and Karatay) from Konya city centre in 2017. In this research it has been observed that elderly individuals and their caregiver relatives have sufficient level of communication skills. However the caregiver relatives' degree of communication skills were found to be more than the elderly individuals' $(p<0.001)$. It is also seen that women $(p<0.01)$, younger ones ( $p<0.001)$, those with a high level of education $(p<0.001)$, those who get social security is the Pension Fund from government $(p<0.05)$ have more communication skills among the sample-group individuals. In general, in the research findings, it was found that education is quite related to individuals' communication skills. As a result, the necessity of formal and non-formal education programs to improve the communication skills of individuals is emphasized.
\end{abstract}

Keywords: Elderly individual, the care giver relatives, communication skills 


\section{Giriş}

Yaşlılık, insan biyolojisindeki kayıpların bir sonucu olarak organizmanın verimliliğinin ve kişinin çevreye uyum sağlayabilme yeteneğinin gittikçe azalmasıdır (Akgün, 2012, s.51). Dolayısıyla yaşlı insanların ezici çoğunluğunun sorunu, hafif engelliliğin ve duyusal kayıpların birikimiyle günlük verimliliğin azalması ve bilgi işlem oranının yavaşlaması ile ilgilidir (Rabbitt ve Carmichael, 1994, s.173). Ayrıca yaşıtlarının ve eşlerinin kaybıyla birlikte sosyal alanlarının her geçen gün daralması, yaşlı bireylerin iletişimsel paylaşımını doğrudan etkilemektedir. Yaşla birlikte artan sağlık problemleri ve geleceğe yönelik beklentilerin azalması, kişinin bedensel sorunlarına ve geçmişteki anılarına yoğunlaşmasına neden olmaktadır. Hatta yakınlarının ölümü (yas), ekonomik yoksunluk ya da şiddetli sağlık problemi (felç, demans, süreğen hastalıklar vb.) gibi nedenlerle başkalarına bağımlı hale gelmek, yaşlının yaşam kalitesi düşürmekte ve yoğun depresyon yaşamasına neden olabilmektedir (Milli Eğitim Bakanlığ [MEB], 2014, s.4,5). Bu durum, yaşlı bireylerin günlük yaşam becerilerinde ve iletişim düzeylerinde kayıplara neden olmakta; çoğunlukla yaşlının kendisini sosyal yaşamdan çekmesiyle sonuçlanabilmektedir. Böyle bir durumda bakım veren aile bireyinin iletişim tarzı, yaşlı bireyin yaşam kalitesini etkileyen hayati bir unsur haline gelir.

Barthel'in Günlük Yaşam Aktiviteleri Ölçeği'ne göre yaşlı bireylerin özbakım yetenekleri; temel yaşam ve enstrümental yaşam becerileri şeklinde s1nıflandırılmıştır. "Temel Günlük Yaşam Becerileri"; yeme/içme, banyo yapma, giyinme/çeki düzen, tuvalete girme, yürüme/gezinme olarak gruplandırılmıştır. Özbakım yetenekleri içinde yer alan "Enstrümental Günlük Yaşam Becerileri" ise sadece kendine bakmakla kalmayıp bağımsız olarak yaşamak için gerekli olan üst düzey becerilerdir. Bunlar merdiven çıkma, alışveriş yapma, yemek pişirme ve evin bakımı şeklinde gruplandırılmıştır (Cankurtaran, 2013, s.84). Dolayısıyla yaşlıya bakım denildiğinde sadece yatağa bağımlı yaşlı anlaşılmamalıdır. Çünkü yaşlı birey temel günlük yaşam becerilerini kendi kendine gerçekleştirebiliyor olsa da evinin temizlenmesi, yemeğinin pişirilmesi, ihtiyaçlarının dışarıdan satın alınması, sağlık tetkiklerinin takip edilmesi gibi enstrümental günlük yaşam becerilerine yardım da yaşlı bakımı içinde yer almaktadır.

Zaten her türlü bakım işleminin öncesi, esnası ve sonrasında bakan ile bakılan arasında dilsel ya da dilsel olmayan (bedensel yakınlık, gözle iletişim, 
gülümseme, dokunma) bir iletişim söz konusudur. Ancak olumlu ve güvenilir bir iletişim için verilen mesajların açık, anlaşılır ve empatiye dayalı olması gerekmektedir. Ayrıca aktif dinlemeye önem verilmeli; böylece yaşlı bireye "Senin için zamanım var", "Sana değer veriyorum" mesajları verilmelidir (Ergin, 2011, s.3,25,49). Nitekim Mehrabian'ın, 1967'de yaptığı iki deneyin bulgularından yola çıkarak duyguların iletişimiyle ilgili geliştirdiği teoriye göre anlamin \% 7'sinin sözcüklerle, \% 38'inin ses tonuyla ve \% 55'inin vücut dili ile (sözsüz) iletildiğini bildirmiştir (Mehrabian, 1972). Bir başka araştırmaya göre de iletişimde sözcüklerin \%10, ses tonunun \%30, beden dilinin $\% 60$ oranında etkili olduğu belirtilmiştir (Cooper,1989, s. 56). Bu durumda denilebilir ki yukarıda dile getirilen nedenlerden dolayı sözlü iletişimin aksamaya başladığı yaşlı iletişiminde (zaten normal iletişimin de büyük bir bölümünü oluşturan) beden dili önemli bir yer tutmaktadır.

Aslında yaşlı bireylerin çoğu mesaj göndermeye ve genel olarak bir şeyler anlatmaya fazlasıyla ihtiyaç duyar. Kendilerini ifade etmek ayn zamanda kendi hayatlarını, tecrübelerini ve görüşlerini paylaşma ve aktarma arzusu içindedirler (Güven ve Yılmaz, 2013, s.158-160). Bu nedenle yaşlı ana babalarla çoğu zaman onlara bakım veren çocukları arasındaki iletişimin sıklığı, yaşlıların kendilerini iyi hissetmelerini sağlamaktadır. Bununla birlikte ilişkilerin niteliği, niceliğinden daha önemlidir. İlişkinin sevgiye dayalı olup olmaması ya da bir zorunluluk duygusuyla gerçekleştirilip gerçekleştirilmemesi, iletişimin niteliğini belirlemektedir. Sonuçta ana baba ve yetişkin çocuklar arası dostça, sevgiye dayalı ilişkiler, ana babaya destek sağlama konusunda motive edici bir öge olarak görülmektedir (İçli,2008, s.37).

Aile merkezli bakım; aile üyesinin davranışı, seçimleri, tutumları veya duyguları söz konusu olduğunda, "zor" veya "zahmetli" gibi görünebilir. Bu özel durumda, bakım verilen aile üyesinin düşünce ve duygularının ifadesi olarak söylediği ya da yaptığı bir şeyi kabul etmek anlamına gelen "onaylama", yararlı bir beceridir. Onaylama, güvenli olmayan davranışı kabul etme anlamına gelmemektedir; sadece bakım verenin, anlaşmazlık söz konusu olduğunda bile yaşlı aile üyesinin endişelerine ve hislerine önem verdiğini, söylediklerini dinlediğini, anladığını, ciddiye aldığını gösterir. Yaşlı aile bireyinin agresif ve kuvvetli duygusal reaksiyonları olsa da, onaylama davranışı çatışmayı en aza indirir; problem çözme becerilerini güçlendirir ve daha iyi bir iletişime teşvik eder (Harvey ve Ahmann, 2014, s.143,145). Kısaca Cüceloğlu'nun (1997) da ifade ettiği gibi “iletişim, bir canın başka bir cana 
değmesidir." ve emek ister. Bu yüzden yaşlı bakımında düzgün ve etkili iletişim, bakım vericilerin vicdanlarına bırakılmayacak kadar önemli bir konudur. Nitekim Fried, Bradley, O'leary ve Byers (2004)'in yaptıkları araştırmada yer alan örneklem grubundaki hem ciddi şekilde hasta olan yaşlıların (\%66.7) hem de bakım vericilerin (\%83.1) büyük bir kısmının, iletişimi artırmak için karşılanmamış bir istek duydukları tespit edilmiştir.

Yukarıda açıklananlar doğrultusunda denilebilir ki; yaşlı birey ve onun bakımını üstlenen yakını arasındaki duygusal bağın yanı sıra iletişimin sağlıklı olması, şüphesiz hem yaşlı bireyin hem de bakım verici aile üyesinin yaşam kalitesini artırmaktadır. Bu nedenle bu araştırmanın amact, yaşlı bireyle onun bakımını üstlenen akrabasının iletişim düzeylerini ölçmek ve her iki tarafın demografik özelliklerinin, iletişim düzeylerine etkisini belirlemektir. $\mathrm{Bu}$ bağlamda, araştırmada aşağıdaki sorulara yanıt aranmıştır:

1- Yaşlı bireyler ve onlara bakım veren akrabalarının iletişim becerisi düzeyleri arasında fark var midır?

2- Yaşlı bireyler ve onlara bakım veren akrabalarının iletişim becerisi düzeyleri ile demografik özellikleri arasında anlamlı bir ilişki bulunmakta midır?

\section{Araştırmanın Yöntem ve Araçları}

Araştırma yöntemi; araştırma modeli, araştırmanın evreni, örneklemi, örneklemin demografik özellikleri, veri toplama araçları ve verilerin analizi alt başliklarıyla sunulmuştur.

\section{Araştırma Modeli}

Araştırmada tarama modeli kullanılmıştır. "Tarama modelleri, geçmişte ya da halen varolan bir durumu varolduğu şekliyle betimlemeyi amaçlayan araştırma yaklaşımlarıdır. Araştırmaya konu olan olay, birey ya da nesne, kendi koşulları içinde ve olduğu gibi tanımlanmaya çalışılır" (Karasar, 2012).

\section{Araştırmanın Evren ve Örneklemi}

Araştırmanın evreni 2017 yılında Konya il merkezini oluşturan Karatay, Selçuklu ve Meram ilçelerinde ikamet eden 60 yaş ve üzerindeki yaşlı bireyler 
oluşturmuş̧tur. Bu yaşlllar evreninden tesadüfi örneklem yöntemi ile seçilen 115 yaşlı birey ve onların bakımını üstlenen 115 akrabası ise araştırmanın örneklemini oluşturmuştur.

Yazıcıoğlu ve Erdoğan'ın (2004) geliştirdikleri örneklem büyüklükleri tablosunda 0.05 örnekleme hatasına göre örneklemin homojen olduğu kabul edildiğinde ( $\mathrm{p}=0.8 ; \mathrm{q}=0.2)$; bizim temel aldığımız evren büyüklüğü $(\mathrm{N}=$ 157.561) için alınması gereken örneklem sayısı 245 olarak belirlenmiş olup, bu çalışmada anket formu 260 kişiye dağıtılmış ancak 230 kişiden geriye dönüş sağlanabilmiştir. Örneklem grubunun \% 35.2'si Karatay ilçesinde, \% 39.1'i Selçuklu ilçesinde, \% 25.7'si Meram ilçesinde ikamet etmektedir.

Örneklem Grubunun Demografik Özellikleri: Araştırmada yer alan örneklem grubu yaşlı bireyler ve bakım verici yakınları olmak üzere iki gruptan oluşmaktadır. Dolayısıyla bu iki grubun demografik özellikleri ayrı ayrı incelenmiştir.

Yaşlı bireylerin demografik özelliklerine göre dağllımlart: Araştırmanın örneklem grubunda yer alan yaşlı bireylerin \%60.0'ı kadın, \%40.0'1 erkektir. Yaşlıların \%40.0'1 70-79 yaş arasında, \%33.9'u 60-69 yaş arasında, \%26.1'i 8090 yaş arasındadır. Yaşlı bireylerin çoğunluğu (\%77.4) ilkokul ve daha az eğitimlidir (hemen hemen 1/3'ü sadece ilkokul mezunu iken 1/3'ü okur-yazar dahi değildir). Katılımcı yaşlıların eğitim düzeylerinin düşüklüğü, yaşları itibariyle Konya'nın geleneksel kesimini oluşturmalarına bağlanabilir. Yaşlı bireylerin medeni durumları incelendiğinde; \%50.4'ü dul (eşi ölmüş), \%49.6'sı evlidir. Örneklemi oluşturan yaşlı bireylerin çoğunluğunun (\%67.8) 3 ve daha fazla çocuğu sahip geleneksel aile yapısını temsil ettiği görülmektedir. Her ne kadar son yasal düzenlemelerle bütün sosyal haklar tek bir çatı altında toplanmış olsa da katılımcıların yarıya yakınının ( \%45.2) SSK, \%27.8' inin BağKur, \%15.7'sinin Emekli Sandığı, \%11.3'ünün Yeşil Kart temelli sosyal güvenceye sahip olduğu bulunmuştur (Tablo 1 ). 
Tablo 1. Yaşlı bireylerin demografik özelliklerine göre dağılımları $(n=115)$

\begin{tabular}{llllll}
\hline Cinsiyet & $\mathbf{N}$ & $\mathbf{\%}$ & Medeni Durum & $\mathbf{n}$ & $\mathbf{\%}$ \\
\hline Kadın & 69 & 60.0 & Evli & 57 & 49.6 \\
\hline Erkek & 46 & 40.0 & Dul (Eşi ölmüş) & 58 & 50.4 \\
\hline Yaş & & Çocuk Sayısı & & 19 & 16.5 \\
\hline 60-69 arası & 39 & 33.9 & Çocuğu olmayan & 4 & 3.5 \\
\hline $70-79$ arası & 46 & 40.0 & 1 çocuğu olanlar & 14 & 12.2 \\
\hline 80-90 arası & 30 & 26.1 & 2 çocuğu olanlar & 31 & 27.0 \\
\hline Eğitim Durumu & & & 3 çocuğu olanlar & 15 & 13.0 \\
\hline Okur-yazar değil & 42 & 36.5 & 4 çocuğu olanlar & 16 & 13.9 \\
\hline Okur-yazar & 10 & 8.7 & 5 çocuğu olanlar & 16 & 13.9 \\
\hline İlkokul & 37 & 32.2 & 6 ve üzeri çocuğu olanlar & & \\
\hline Ortaokul & 10 & 8.7 & Sahip Olunan Sosyal Gü- & & \\
& & & vence & 52 & 45.2 \\
\hline Lise & 9 & 7.8 & SSK & 32 & 27.8 \\
\hline Üniversite & 7 & 6.1 & Bağ-Kur & 18 & 15.7 \\
\hline & & Emekli Sandı̆̆1 & 13 & 11.3 \\
\cline { 2 - 6 } & & & Yeşil Kart & & \\
\hline
\end{tabular}

Yaşlıya bakım veren yakınlarnın demografik özelliklerine göre dağılımlarn: Araştırmanın örneklem grubunda yer alan yaşlısına bakım veren bireylerin \%60.0'1 kadın, \%40.0'1 erkektir. Bakım verici grubun çoğunluğu (\%39.1) 45 yaş ve üzerinde olup, bu grubu 34 yaş ve altındakiler (\% 34.8) ve 35-44 yaş arasındakiler (\%26.1) izlemiştir. Yaşlısına bakım verenlerin çoğunluğu (\%37.4) üniversite mezunu ve ilkokul mezunu (\%30.4) olup, bu grubu sirasiyla lise mezunu (\%16.5), ortaokul mezunu (\%9.6) ve okur-yazar olanlar (\%6.1) takip etmiştir. Yaşlısına bakım veren örneklem grubu mesleki açıdan incelendiğinde, grubun yarıya yakınının (\%46.1) ücretli bir işte çalışmadığı (ev kadını/emekli/işsiz), diğer mesleklerin ise sırasıyla işçi (\%17.4), serbest meslek sahibi (\%15.6), öğrenci (\%11.3), memur (\%9.6) olduğu görülmüştür. Bakım verici katılımcıların yarıdan fazlası (\% 60.0) SSK temelli sosyal güvenceye sahiptir. Örneklemin bakım veren grubunu oluşturanların yarısından fazlası (\%58.3) evlidir. Evli olanların da çoğunluğu çocuksuz (\%40.9) ya da 2 çocukludur (\%25.2). Bakım verenlerin çocuk sahibi olma oranı, yaşlı grupla karşılaştırıldığında, genç neslin daha az çocuk sahibi olma eğiliminde olduğu gözlenmiştir. Ayrıca yaşlısına bakım verenlerin çoğunluğu, yaşlı bireyle kan bağı olan yakın akrabası olup ilk sırada kız evlat (\%27.8) ve erkek evlat (\%24.4) yer almaktadır (Tablo 2). 
Tablo 2. Yaşlıya bakım veren yakınının demografik özelliklerine göre dağılımı $(n=115)$

\begin{tabular}{|c|c|c|c|c|c|}
\hline Cinsiyet & $\mathbf{n}$ & $\%$ & Mesleği & $\mathbf{n}$ & $\%$ \\
\hline Kadın & 69 & 60.0 & Ev kadını & 42 & 36.5 \\
\hline Erkek & 46 & 40.0 & Emekli & 8 & 7.0 \\
\hline Yaş & & & Memur & 11 & 9.6 \\
\hline 34 ve daha az & 40 & 34.8 & İşçi & 20 & 17.4 \\
\hline $35-44$ arası & 30 & 26.1 & Serbest meslek sahibi & 18 & 15.6 \\
\hline 45 ve üzeri & 45 & 39.1 & İşsiz & 3 & 2.6 \\
\hline Eğitim Durumu & & & Öğrenci & 13 & 11.3 \\
\hline Okur-yazar & 7 & 6.1 & Çocuk Sayısı & & \\
\hline İlkokul & 35 & 30.4 & Çocuğu olmayan & 47 & 40.9 \\
\hline Ortaokul & 11 & 9.6 & 1 çocuğu olanlar & 7 & 6.1 \\
\hline Lise & 19 & 16.5 & 2 çocuğu olanlar & 29 & 25.2 \\
\hline Üniversite & 43 & 37.4 & 3 çocuğu olanlar & 22 & 19.1 \\
\hline $\begin{array}{l}\text { Sahip Olunan Sosyal Gü- } \\
\text { vence }\end{array}$ & & & $\begin{array}{l}4 \text { ve üzerinde çocuğu } \\
\text { olanlar }\end{array}$ & 10 & 8.7 \\
\hline SSK & 69 & 60.0 & $\begin{array}{l}\text { Yaşlıya Yakınlık Dere- } \\
\text { cesi }\end{array}$ & & \\
\hline Bağ-Kur & 22 & 19.1 & K1Z1 & 32 & 27.8 \\
\hline Emekli Sandığı & 18 & 15.7 & Oğlu & 28 & 24.4 \\
\hline Yeşil Kart & 6 & 5.2 & Gelini & 13 & 11.3 \\
\hline Medeni Durum & & & Torunu & 10 & 8.7 \\
\hline Evli & 67 & 58.3 & Kardeşi & 5 & 4.4 \\
\hline \multirow[t]{3}{*}{ Bekar } & 48 & 41.7 & Eşi & 3 & 2.6 \\
\hline & & & Damadı & 2 & 1.7 \\
\hline & & & Uzaktan akrabası & 22 & 19.1 \\
\hline
\end{tabular}

\section{Araştırmada Kullanılan Veri Toplama Araçlan}

Araştırmanın verileri bireylerle yüz yüze uygulanan anket tekniği ile toplanmıştır. Anket formunda öncelikle bireylerin demografik özelliklerini oluşturan kapalı uçlu (cinsiyet, eğitim durumu, mesleği, medeni durumu, sahip olduğu sosyal güvence) ve açık uçlu (yaş, çocuk sayısı, yaşlı bireye yakınlık derecesi) kişisel sorular yer almıştır. Anket formunda ayrıca yaşlı bireyin ve bakım verenin iletişim becerilerini ölçen "İletişim Becerileri Ölçeği" yer almiştır.

İletişim Becerileri Ölçeği: İlk olarak Balcı (1996) tarafından geliştirilmiş ve kullanılmıştır. Gerekli geçerlik ve güvenirlik çalışmaları yapılan ölçeğin bu ilk sürümünün madde sayısı 70'tir. Ölçek daha sonra tekrar, Ersanlı ve Balcı (1998) tarafından 500 üniversite öğrencisinden oluşan bir örnekleme uygu- 
lanmış, yapılan faktör analizi sonucunda madde sayısı 45'e indirilmiştir. Ölçek zihinsel, duygusal ve davranışsal açıdan iletişim becerilerini ölçmektedir. Her bir boyutu ölçen 15 madde vardır. Her boyuta giren maddeler aşağıda görülmektedir:

Zihinsel: 1,3,6,12,15,17,18,20,24,28,30,33,37,43,45

Duygusal: 5,9,11,26,27,29,31,34,35,36,38,39,40,42,44

Davranışsal: 2,4,7,8,10,13,14,16,19,21,22,23,25,32,41

Maddeler, "her zaman", "genellikle", "bazen", "nadiren”, "hiçbir zaman” olarak yanıtlanmaktadır. Boyutlarda ve genel (toplam) iletişim becerisinde yüksek puan, daha yüksek iletişim becerisine karşıllk gelmektedir.

Ölçeğin Geçerliği ve Güvenirliği: Bu çalışmada yapılan istatistiksel analiz sonucunda "İletişim Becerileri Ölçeği" nin yeterli güvenirlik düzeyine sahip olduğu (Alpha = 0.806) bulunmuş olup; ölçeğin geçerliğini sınamak için doğrulayıcı faktör analizi yapılmıştır. Doğrulayıcı faktör analizini yaparken öncelikle alt faktör grupları orijinal ölçekte olduğu gibi zihinsel, duygusal ve davranışsal olmak üzere üç grupta belirlenmiş ve adlandırılmıştır. Doğrulayıcı faktör analizine göre her ne kadar CMIN/DF $\left(\chi^{2} / s d\right)$ düzeyi 5 ten küçük; RMSEA değeri $0.09(<0.10)$ bulunmuş olmakla birlikte; GFI, AGFI ve CFI değerleri 0.90 'dan büyük olması gerekirken 0.44 ile 0.46 değerleri arasında bulunmuştur. Bu durumda model uyumluluğu doğrulayıcı faktör analizi ile test edilememiş, yeniden açımlayıcı faktör analizine ihtiyaç duyulmuştur. Dolayısıyla ölçeğin geçerliğini sınamak ve alt boyutlarını tespit etmek amacıyla yapılan açımlayıcı faktör analizi sonuçları aşağıda açıklanmıştır.

Veri setinin faktör analizine uygunluğunu test edebilmek için, Kaiser-Meyer-Olkin (KMO) örneklem yeterliliği testi uygulanmıştır. Etkinlik ölçeğinin geçerliğinin $\mathrm{KMO}$ değeri 0.50'nin üzerinde olduğundan ve Bartlett testi de 0.05 önem derecesinde anlamlı olduğundan, veri seti faktör analizine uygun bulunmuştur $(\mathrm{KMO}=0.818 ; \chi 2$ Bartlett test $(861)=4.078 \mathrm{E} 3 ; \mathrm{p}=0.0001)$ (Tablo 3).

Temel bileşenler yöntemi ve Varimax dik döndürme yöntemi kullanılarak ölçek analiz edilmiştir. Faktör ağırlığ 10.30 'un altında kalan 3 önerme $(18$, 26, 31) elenmiş ve ölçekteki madde sayısı $45^{\prime}$ ten $42^{\prime}$ ye düşmüştür. Analiz sonucunda özdeğerleri 1 ve üzerinde olan iki faktör elde edilmiştir. 25 ifadeyi içeren birinci faktör "Olumlu iletişim alışkanlıkları" ve ters cümle şeklinde kodlanmış olan, 17 ifadeyi içeren ikinci faktör "Olumsuz iletişim alışkanlıkları" 
Yaşlı Bireylerin ve Onlara Bakım Veren Akrabalarının İletişim Becerilerinin İncelenmesi: Konya İli Örneği

şeklinde adlandırılmıştır. Faktörlerin içsel tutarlılıklarının hesaplanmasında da Cronbach Alpha değerleri kullanılmış ve faktörlerin 0.60 güvenirlik düzeyinin üzerinde olduğu (bu değerler sirasıyla 0.910 ve 0.820 'dir) ve yapılacak analizler için kullanılabilir yeterlilikte olduğu tespit edilmiştir. Toplam açılanan varyans \% 31.640 bulunmuştur (Tablo 3).

Tablo 3. "İletişim becerileri ölçeği"nin açımlayıcı faktör analizi sonuç tablosu

\begin{tabular}{|c|c|c|c|}
\hline İletişim İfadeleri & $\begin{array}{l}\text { Faktör } \\
\text { Ağırlıkları }\end{array}$ & $\begin{array}{l}\text { Faktörün } \\
\text { Açıklayı- } \\
\text { cılığı (\%) }\end{array}$ & $\begin{array}{l}\text { Güvenir- } \\
\text { lik }\end{array}$ \\
\hline 8. Karşımdaki kişiye genellikle söz hakkı veririm. & 0.681 & \multirow{25}{*}{21.258} & \multirow{25}{*}{0.910} \\
\hline 14. Konuşurken açık, sade ve düzgün cümleler kurarım. & 0.681 & & \\
\hline $\begin{array}{l}\text { 15. Karşımdaki kişiyle aynı görüşü paylaşmasam bile fikirlerine saygı } \\
\text { duyarım. }\end{array}$ & 0.674 & & \\
\hline $\begin{array}{l}\text { 7. Kişilerin, anlatmak istediklerini dinlemek için yeterince zaman ayı- } \\
\text { rırım. }\end{array}$ & 0.653 & & \\
\hline $\begin{array}{l}\text { 45. Kendimi karşımdaki kişinin yerine koyarak, duygu ve düşüncele- } \\
\text { rini anlamaya çalışırım. }\end{array}$ & 0.641 & & \\
\hline $\begin{array}{l}\text { 33. İletişim kurduğum kişinin tutumundan daha çok sorununu anla- } \\
\text { maya çalışırım. }\end{array}$ & 0.627 & & \\
\hline 21. İnsanlarla görüşürken, bilerek onları rahatlatacak şeyler yaparım. & 0.618 & & \\
\hline 22. Dinlerken, karşımdaki kişinin sözünü kesmemeye özen gösteririm. & 0.608 & & \\
\hline 19. Dinlediğim kişiyi daha iyi anlamak için sorular yöneltirim. & 0.607 & & \\
\hline $\begin{array}{l}\text { 2. İletişimde bulunduğum insanlardan gelen öğüt ve önerileri içten- } \\
\text { likle dinlerim. }\end{array}$ & 0.607 & & \\
\hline $\begin{array}{l}\text { 40. İletişim kurduğum kimselerden bir şeyler alır ve onlara da bir şey- } \\
\text { ler verdiğimi hissederim. }\end{array}$ & 0.594 & & \\
\hline 4. Konuşurken, etkili bir göz iletişimi kurabilirim. & 0.580 & & \\
\hline 1. İnsanları anlamaya çalışırım. & 0.575 & & \\
\hline 12. Eleştirilerimi karşımdaki kişiyi incitmeden iletirim. & 0.573 & & \\
\hline $\begin{array}{l}\text { 20. Dinleyenim anlamaz göründüğünde, iletmek istediklerimi tekrar- } \\
\text { lar, yeni kelimelerle ifade eder, özetlerim. }\end{array}$ & 0.571 & & \\
\hline $\begin{array}{l}\text { 17. Karşımdaki kişinin konuşmaya ve dinlenmeye istekli olup olmadı- } \\
\text { ğını anlamaya çalışırım. }\end{array}$ & 0.559 & & \\
\hline 6. Dikkatimi karşımdakinin ilgi alanı üzerinde toplayabilirim. & 0.539 & & \\
\hline 25. Ses tonumu konunun özelliğine göre ayarlayabilirim. & 0.503 & & \\
\hline 44. İletişim kurduğum insanlar tarafından anlaşıldığımı hissederim. & 0.495 & & \\
\hline $\begin{array}{l}\text { 43. Öneride bulunduğum kişinin öneriye açık olup olmadığına dikkat } \\
\text { ederim. }\end{array}$ & 0.491 & & \\
\hline 39. Her insanı olumlu beklentilerle karşılarım. & 0.489 & & \\
\hline 38. Karşımdaki kişiye güvenmek beni mutlu eder. & 0.468 & & \\
\hline 13. Konuşurken ilk adımı atmaktan çekinmem. & 0.382 & & \\
\hline $\begin{array}{l}\text { 30. Tartışma sonunda, savunduğum düşüncelerin yanlış olduğunu } \\
\text { kabul edebilirim. }\end{array}$ & 0.367 & & \\
\hline $\begin{array}{l}\text { 36. İletişim kurduğum kimse tarafından anlaşılmaktan mutluluk du- } \\
\text { yarım. }\end{array}$ & 0.352 & & \\
\hline 32. İnsanları kontrol etmeye ve istediğim kalıba sokmaya çalışırım. (-) & 0.625 & \multirow[b]{2}{*}{10.382} & \multirow[b]{2}{*}{0.820} \\
\hline $\begin{array}{l}\text { 16. İletişimde bulunduğum kişinin yüzüne baktığım halde sözlerini } \\
\text { dinlemediğim olur. (-) }\end{array}$ & 0.589 & & \\
\hline
\end{tabular}




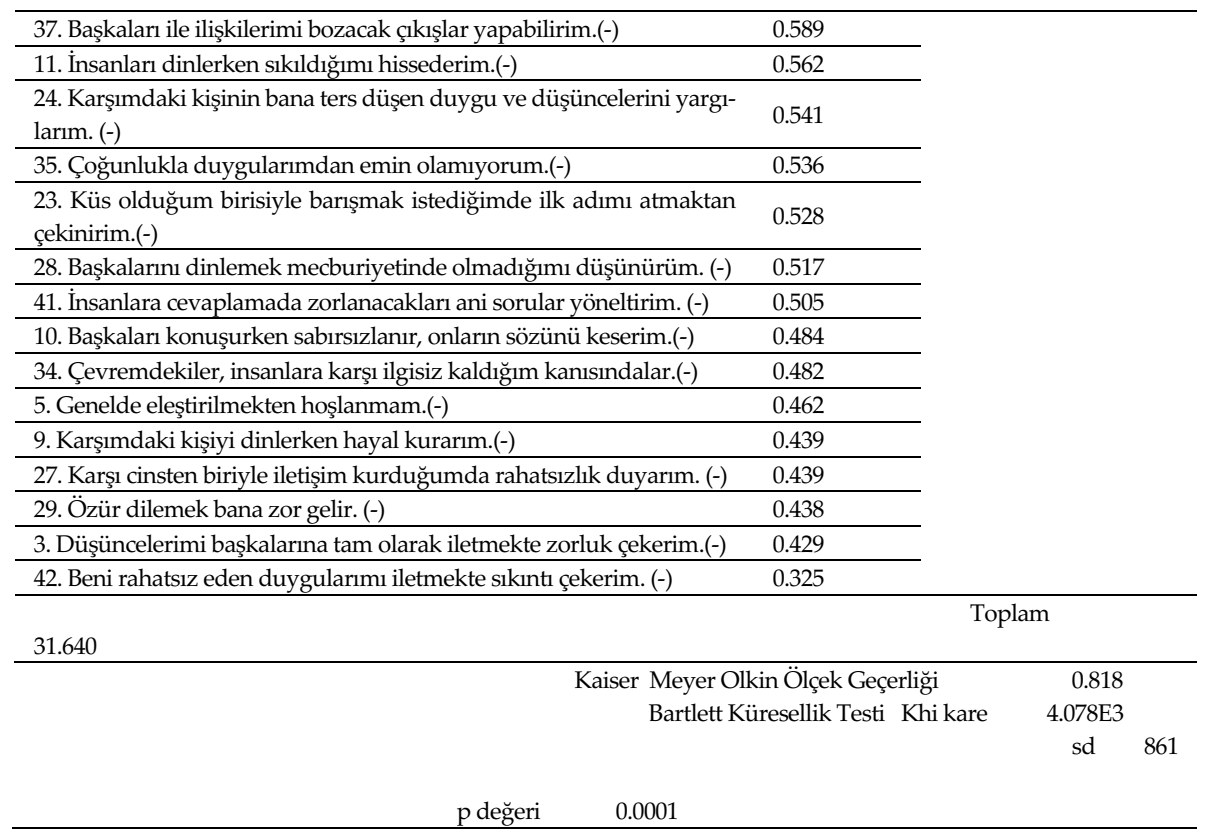

\section{Verilerin Analizi}

Örneklem grubunda yer alan yaşlı bireylerin ve yaşlısına bakım verenlerin "İletişim Becerileri Ölçeği"ne yönelik puanlarını karşılaştırmak için bağımsız gruplarda t-testi uygulanmıştır.

Ayrıca örneklem grubunun demografik özellikleri ile iletişim becerisi puanları arasındaki ilişkinin varlığı, Pearson Korelasyon Katsayısı hesaplanarak irdelenmiştir. Bir de katılımcıların iletişim becerisi düzeylerinin ilişkili bulunduğu demografik özelliklerden eğitim düzeyi ve sosyal güvence değişkeninin alt boyutları arasındaki puan farkını ortaya çıarmak için One-Way Anova testi uygulanmış; yaş değişkeninin alt boyutları arasındaki puan farkını ortaya çıkarmak için bağımsız gruplarda t-testi yapılmıştır.

\section{Bulgular}

\section{Örneklem Grubunun İletişim Becerisi Düzeylerinin İncelenmesi}

Tablo 4'e göre hem yaşlı bireylerin, hem de yaşlısına bakım veren bireylerin iletişim puanı ortalamaları 3.40'ın üzerinde olduğu için olumlu iletişim alışkanlıklarını "genellikle" gerçekleştirdikleri görülmüştür. 
Aynı tabloda yaşlı bireylerin ve yaşlısına bakım verenlerin iletişim becerisi düzeyleri karşılaştırıldığında; her iki grup da olumlu iletişim becerilerine yeterince sahip olmakla birlikte yaşlısına bakım veren bireylerin toplam iletişim becerilerinin ( $\bar{X}=3.63$ ), yaşlı bireylere ( $\bar{X}=3.41$ ) göre daha fazla olduğu gözlenmiştir. Bu bulgu istatistiksel olarak da anlamlı bulunmuştur $(\mathrm{p}<0.001)$.

Tablo 4: Yaşlı bireylerin ve yaşlısına bakım verenlerin iletişim becerisi düzeylerinin $\mathrm{t}$ testi sonuçları $(\mathrm{n}=230)$

\begin{tabular}{|c|c|c|c|c|c|c|c|}
\hline & Örneklem Grubu & $\mathbf{n}$ & $\bar{X} \pm S_{\bar{X}}$ & $S_{\mathrm{x}}$ & Sd & $t$ & p \\
\hline $\begin{array}{l}\text { İletişim } \\
\text { Becerisi } \\
\text { Düzeyi } \\
\end{array}$ & $\begin{array}{l}\text { Yaşlı Birey } \\
\text { Bakım Veren Birey }\end{array}$ & $\begin{array}{l}115 \\
115\end{array}$ & $\begin{array}{l}3.41 \pm 0.04 \\
3.63 \pm 0.04\end{array}$ & $\begin{array}{l}0.43 \\
0.46\end{array}$ & 228 & -3.735 & $0.0001^{* * *}$ \\
\hline $\begin{array}{l}{ }^{*} \mathrm{p}<0.05 \\
\bar{x}=3.40\end{array}$ & $\begin{array}{l}{ }^{* *} \mathrm{p}<0.01 \\
\text { e üzeri*: Olumlu }\end{array}$ & letiş & $\begin{array}{l}{ }^{* * *} \mathrm{p}<0.001 \\
\text { "'genellikle }\end{array}$ & erçek & renle & & \\
\hline
\end{tabular}

Araştırmaya katılan bireylerin yanıtladıkları "İletişim Becerileri Ölçeği”" puanları ile demografik özellikleri (yaş, cinsiyet, medeni durum, çocuk sayısı, eğitim durumu, ücretli bir işte çalışma durumu ve sosyal güvencesi) arasında ilişkinin varlığı Tablo 5 'te incelenmiştir.

Tablo 5. Örneklem grubunun "Illetişim becerileri ölçeği" puanlarnnı demografik değişskenlere göre pearson korelasyon katsayısı $(n=230)$

\begin{tabular}{cccccccc}
\hline & Yaşı & Cinsiyeti & $\begin{array}{l}\text { Medeni } \\
\text { Durumu }\end{array}$ & $\begin{array}{l}\text { Çocuk } \\
\text { Sayıs }\end{array}$ & $\begin{array}{l}\text { Ĕğitim } \\
\text { rumu }\end{array}$ & $\begin{array}{l}\text { Çalşma } \\
\text { Durumu }\end{array}$ & $\begin{array}{l}\text { Sosyal Gü- } \\
\text { vencesi }\end{array}$ \\
\hline $\begin{array}{l}\text { Illetişim Be- } \\
\text { cerisi }\end{array}$ & $\mathbf{- 0 . 2 2 9 ^ { * * * }}$ & $\mathbf{- 0 . 1 8 5 ^ { * * }}$ & -0.024 & -0.083 & $\mathbf{0 . 2 3 6 * *}$ & -0.003 & $\mathbf{0 . 1 4 8}^{*}$ \\
\hline${ }^{*} \mathrm{p}<0.05$ & & & ${ }^{* *} \mathrm{p}<0.01$ & & ${ }^{* * *} \mathrm{p}<0.001$ & &
\end{tabular}
*(1) Kadın
(2) Erkek

Yaş ile iletişim becerisi ilişkisi: Tablo 5 incelendiğinde; örneklemde yer alan bireyler arasında yaşça küçük olanların, yaşça büyük olanlara göre iletişim becerilerinin daha fazla olduğu görülmüştür $(r=-0.229 ; \mathrm{p}<0.001)$. Örneklemin yaş gruplarına göre iletişim becerisi farkları ayrıca t-testi ile incelendiğinde; 
59 yaş ve altındakilerin ( $\bar{X}=3.68)$; 60 yaş ve üzerindekilere ( $\bar{X}=3.47$ ) göre iletişim becerisi düzeylerinin yüksek olduğu bulunmuştur $(\mathrm{t}=3.511 ; \mathrm{p}<0.01)$. Bu sonuç yaşça küu̧ük olan bakım vericilerin, yaşça büyük olan yaşlılara göre daha çok iletişim becerisine sahip olduğu bulgusunu da desteklemektedir.

Cinsiyet ile iletişim becerisi ilişkisi: Katılımclar arasında kadınların, erkeklere göre iletişim becerisinin daha fazla olduğu istatistiksel olarak anlamlı bulunmuştur $(\mathrm{r}=-0.185 ; \mathrm{p}<0.01)$ (Tablo 5).

Eğitim düzeyi ile iletişim becerisi ilişkisi: Örneklem grubu içinde eğitim düzeyi yüksek olanların, eğitim düzeyi düşük olanlara göre iletişim becerisi puanlarının daha yüksek olduğu tespit edilmiştir $\quad(r=0.236 ; p<0.001)$ (Tablo 5). Katılımcların eğitim düzeylerinin alt gruplara göre iletişim becerisi farkları ayrıca One-way ANOVA testi ile incelendiğinde; özellikle okur-yazar olmayanların ( $\bar{X}=3.38$ ), okur-yazarların ( $\bar{X}=3.41$ ) ve ortaokul mezunlarının ( $\bar{X}=$ 3.35), üniversite eğitimlilere ( $\bar{X}=3.79$ ) göre iletişim becerisi düzeylerinin daha düşük olduğu saptanmıştır (FWelch= 5.664; $\mathrm{p}<0.001$; FBrown-Forsythe = 5.774; $\mathrm{p}<0.001$ ). Dolayısıyla katılımcılar arasında özellikle üniversite mezunlarının iletişim becerilerinin daha fazla olduğu görülmüştür.

Sosyal güvence ile iletişim becerisi ilişkisi: Araştırmaya yanıt verenler arasında sosyal güvencesi Emekli Sandığı olanların iletişim becerilerinin, diğer sosyal güvence türlerine sahip olanlara göre daha fazla olduğu belirlenmiştir $(\mathrm{r}=0.148 ; \mathrm{p}<0.05)$. Katılımclların sosyal güvencelerinin alt gruplarına göre iletişim becerisi farkları One Way ANOVA testi ile incelendiğinde de; sosyal güvencesi Emekli Sandığı olanların ( $\bar{X}=3.86$ ) iletişim becerisi düzeylerinin, sosyal güvencesi SSK ( $\bar{X}=3.52$ ) ve Bağ-Kur ( $\bar{X}=3.46$ ) olanlara göre daha yüksek olduğu saptanmıştır ( $F_{\text {Anova }}=6.905 ; \mathrm{p}<0.0001$ ). Diğer bir ifade ile katılımcılardan memur olanların iletişim becerilerinin, işçi ve serbest meslek sahiplerine göre daha yüksek olduğu söylenebilir. Memurlar Emekli Sandığına bağlı olmakta ve genellikle memurluk statüsü daha yüksek eğitim gerektirmektedir. Eğitim düzeyi yüksek olanların iletişim becerisi de yukarıda belirtildiği gibi daha fazla olmaktadır. Dolayısıyla Emekli Sandığından emekli olmak, yüksek eğitim seviyesine karşılık gelmektedir. 
Örneklem grubunun medeni durumları ( $p>0.05)$, çocuk sayıları ( $p>0.05)$ ve ücretli bir işte çalışma durumları $(\mathrm{p}>0.05)$ ile iletişim becerileri arasında anlamlı bir ilişki bulunmamıştır (Tablo 5).

\section{Tartışma ve Sonuç}

\section{Yaşh Bireyler ile Bakım Verici Akrabalarının İletişim Düzeyi Farkı}

Yapılan araştırmada, yaşlı bireylerin de onlara bakım veren yakın akrabalarının da olumlu iletişim becerilerine yeterli düzeyde sahip oldukları gözlense de; yaşlısına bakım verenlerin iletişim becerilerinin, yaşl bireylere göre daha fazla olduğu saptanmıştır $(\mathrm{p}<0.001)$.

Her ne kadar yaşlı insanların uzun yaşam deneyimleri ve gençlerden daha zengin olan kelime hazineleri sayesinde, iletişimde alıcı ve verici statüsünde (mesajların gönderilmesi ve alınmasında) gençlere oranla daha yetenekli ve tecrübeli olmaları beklense de durum her zaman böyle olmaz. Çünkü fizyolojik, bireysel ve psiko-sosyal şartların farklılığı, yaşlıların iletişiminde değişimler yaşamasına neden olmaktadır (MEB, 2014, s.3). Yaşlılıkta duyuların kaybı, özellikle işitme duyusu genellikle yaşla birlikte azalmaktadır. Bu dönemde öncelikle yüksek frekanslı (tiz) sesleri işitme yeteneğinde azalma görülür. İşitme yeteneğindeki düşüşe paralel olarak yaşlı bireylerin konuşma mekanizmalarında da bozulmalar meydana gelmektedir (Turan, 2014, s.227; Yıldırım Kaptanoğlu, 2012, s.12). Yaşlılıkta görülen ağız kuruluğunun beraberinde diş kayıpları ve protezlerin yokluğu konuşma bozukluğuna neden olmaktadır. Yaşlıların "en bilinen sözcükleri bile hatırlayamaz olmaları" sözcük bulma güçlükleri yaşla birlikte en çok etkilenen bilişsel sorun olup, iletişimlerini azaltmakta ve dil yeterliliklerinin başkaları tarafından "zayıf" olarak değerlendirilmesine neden olmaktadır (Akgün, 2012: s.52,54). Özellikle ilerleyen yaşla birlikte sağ ve sol beyinde oluşabilen hasarlar ve beyin-damar hastalıkları da dil ve konuşma sorunlarını artırmaktadır. Örneğin inme sonrasında, özellikle beynin sol yarısının hasardan etkilenmesi, "Afazi”yi ortaya çıkarabilir; ya da sağ beynin etkilenmesi ile bilişsel ve dil bozuklukları gözlenir. Demans ve Alzheimer demansında bilişsel yetiler ilerleyici bir şekilde hasar görür; bu da kişinin entelektüel ve sosyal yeteneklerini, günlük işlevlerini olumsuz etkiler. Parkinson hastalığında ise istemsiz kas hareketlerinin yanı sıra yutma ve konuşma zorluğu yaşanır (Maviş ve Özbabalık, 2006, 
s.4,6,10). Yukarıda belirtilen tüm bu nedenlerden dolayı duyulardaki ya da beyin fonksiyonlarındaki azalmalar, yaşlı bireyin iletişim becerisini olumsuz etkilemektedir.

Ancak örneklem grubu içinde yaşlı bireylerin iletişim becerisi yeterli puana sahip olmakla birlikte yaşça daha küçük olan bakım vericilerden daha düşük olmasını sadece duyusal kayıplarla açıklamak doğru olmaz. Tablo 3 'te ölçme aracındaki maddelerin incelendiği açımlayıcı faktör analizi tablosunda görüldüğü üzere iletişim becerisi empati kurmayı, karşı tarafın duygularına önem vermeyi, önyargılı olmamayı ve olaylara olumlu yönden bakmayı gerektirmekte; yaşam deneyimi ile gelişebileceği gibi eğitimle de geliştirilebilmektedir. Nitekim Korkut'un (2005, s. 143) da belirttiği gibi iletişim becerilerinin doğuştan ve sezgi yoluyla gerçekleştiği düşünülse de iletişim tekniklerinin çoğu öğesi öğrenilebilir ve öğretilebilir özellikler göstermektedir. Unutulmamalıdır ki eski kuşaklar her ne kadar yaşam deneyimine sahip olsa da yeni kuşaklar kadar kolay teknolojiyi takip edememekte, internetten yeni bilgileri edinememekte, geleneklerine bağlı kalarak yeni kuşaktaki değişimlere adapte olamadıkları için düşüncelerinde esnek olamamakta ve zaman zaman önyargılı hareket edebilmektedir. Bu nedenle örneklem grubunun demografik özelliklerinde (Tablo 1 ve Tablo 2) görüldüğü üzere bakım vericilerin eğitim düzeyinin (\% 63.5'i ortaokul ve üzeri eğitimli), yaşlı bireylere (\% 77.4'ü ilkokul ve daha az eğitimli) göre daha yüksek olmasının, söz konusu iletişim becerisi farkını açıkladığı öngörülebilir.

\section{Örneklem Grubunun İletişim Düzeyleri ile Demografik Özellikleri Arasındaki İlişki}

Yaşlı bireyler ve onlara bakım veren akrabalarından oluşan örneklem grubunun iletişim becerisi düzeyleri ile demografik özelliklerinden yaş, cinsiyet, eğitim ve sosyal güvence arasında anlamlı ilişki bulunmuş olup aşağıda sadece cinsiyet ve eğitim üzerinden ayrı ayrı tartışılmıştır. Ancak yaş değişkeni yaşlı bireyle ona bakım veren akrabasının yaş farkını yansıttığı ve yukarıda iki grup arasındaki iletişim farkı zaten incelendiği için bu bölümde tekrar ele alınmamıştır. Sosyal güvence de eğitim durumuyla ilişkili görüldüğü için ayrıca tartışılmamıştır. 
Örneklem grubunun iletişim düzeyine cinsiyetin etkisi: Araştırma bulgularinda kadınlarn, erkeklere göre iletişim becerisine daha çok sahip olduğu tespit edilmiştir ( $p<0.01$ ). Farklı çalışma gruplarını içeren alan yazında araştırma bulgumuzla tutarlı bulgular olduğu gibi (Çetinkaya, 2011; Durukan ve Maden, 2010; Erigüç ve Eriş, 2013; Erigüç, Şener ve Eriş, 2013; Gölöcü ve Karcı, 2010; Karatekin, Sönmez ve Kuş, 2012; Koç, Terzi ve Gül, 2015; Koponen, Pyörälä ve Isotalus, 2012; Korkut, 1996; Korkut, 2005; Nacar, 2010; Özerbaş, Bulut ve Usta, 2007; Özşaker, 2013; Reed, McLeod ve McAllister, 1999; Toy, 2007), iletişim becerilerinin cinsiyete göre farklılaşmadığı sonucuna ulaşan araştırmalar da bulunmaktadır (Arslantaş, 1998; Baykara Pehlivan, 2005; Bingöl ve Demir, 2011; Erözkan, 2005; Görmüş, Aydın ve Ergin, 2013; Gülbahçe, 2010; Igbo ve Ikpa, 2013; Özşaker, 2013; Power ve Lennie, 2012; Saracaloğlu, Yenice ve Karasakaloğlu, 2009; Tunçeli, 2013; Ulukan, 2012). İletişim becerileri ile cinsiyet arasındaki ilişkiye yönelik bulgulardaki bu farklılık, araştırmacılar tarafından farklı envanterlerin kullanılması ile açıklanabileceği gibi; seçilen örneklemin toplumsal cinsiyet rolleri, sosyalleşme düzeyleri ve eğitim düzeyleri açısından farklılıklar içermesine de bağlanabilir.

Örneklem grubunun iletişim düzeyine eğitimin etkisi: Araştırmaya katılanların eğitim düzeyleri yükseldikçe (özellikle üniversite eğitimliler arasinda) iletişim becerilerinin de arttığı saptanmıştır ( $p<0.001$ ). Bu bulgu, eğitim düzeyi daha yüksek olan bakım vericilerin (\% 63.5'i ortaokul ve üzeri eğitimli) eğitim düzeyi daha düşük olan yaşlı bireylere (\% 77.4'ü ilkokul ve daha az eğitimli) göre iletişim becerisinin daha fazla olmasını da açıklamaktadır (Tablo 1 ve Tablo 2).

Literatürdeki diğer çalışmalarda da hemşirelerin eğitim düzeyinin, yaşlı hastalarıyla iletişim kurma şekilleriyle güçlü şekilde ilişkili olduğu (Wilma vd., 2001) bulgusu bizim çalışmamızı doğrudan desteklerken; akademik başarının bireylerde iletişim becerisini artırdığ (Bingöl ve Demir, 2011) ve ebeveynlerin eğitim düzeyinin yüksek olmasının, çocuklarının iletişim becerisini artırdığı (Karatekin, Sönmez ve Kuş, 2012) yönündeki bulgular dolaylı olarak desteklemiştir. 


\section{Öneriler}

Elde edilen bulgular doğrultusunda denilebilir ki, halkın yaşam doyumunu artırmak ve ruh sağlığını geliştirmek için yurt çapında iletişim becerisi eğitiminin desteklenmesi gerekmektedir. Bu amaçla kısa vadede bireylerin farkındalıklarını artırmak ve iletişim becerilerini geliştirmek için halk eğitimi programlarının yaygınlaştırılması gerekmektedir. Bu bağlamda YÖK, MEB ve Belediyelerin işbirliği ile halka "İletişim Becerileri Eğitimi" verilmelidir. Ayrıca "Yaşlı Hasta Bakımı" müfredatının içinde "Etkili İletişim Teknikleri Eğitimi" de ağırlıklı olarak verilebilir. Ayrıca unutulmamalıdır ki iletişim iki taraflıdır ve tek taraflı çaba çoğu zaman etkisiz kalabilmektedir. Bu nedenle bakım verici bireyin yanı sıra eve bağımlı hale gelen ve tek eğlenceleri televizyon izlemek olan yaşlı bireylerin de medya programlarında yayınlanan kamu spotları aracılığıyla etkili iletişim konusunda eğitilmesi gerekmektedir. Nitekim yapılan deneysel araştırmalarda, doktorlara (Finset, Ekeberg, Eide ve Aspegren, 2003; Claramita ve Majoor, 2006), sağlık çalışanlarına (Connolly vd., 2014), hasta yakınlarına ve hastane çalışanlarına (Takahashi, Tanaka ve Miyaoka, 2006), tıp öğrencilerine (Koponen, Pyörälä ve Isotalus, 2012), sivil savunma çalışanlarına (Igbo ve Ikpa, 2013), ebeveynlere (Thistle ve McNaughton (2015), 1,5-3 yaşları arasındaki çocuklara (Wang, Lekhal, Aarø ve Schjølberg, 2012) iletişim becerisi eğitimi verildiğinde, iletişim becerilerinde kayda değer gelişmeler olduğu görülmüştür.

$\mathrm{Bu}$ araştırmada bireylerin iletişim becerileri bizzat kendilerine uygulanarak ölçülmüştür. İleride yapılacak araştırmalarda bakım vericinin iletişim düzeyi yaşlı bireye sorularak, yaşlı bireyin iletişim düzeyi bakım vericiye sorularak ölçülebilir. Çünkü yaşlı bireyin ona bakım veren kişiye dair öngörüleri, yaşlı bakımında iletişim modelini yapılandırmak açısından önemlidir. Diğer taraftan, araştırma bulgularının yaşlı bireylerin ve bakım vericilerinin iletişim becerilerinin incelendiği oldukça sınırlı sayadaki alan yazına katkı sağlayacağı düşünülmektedir. Araştırmanın bir diğer katkısı ise, iletişim becerilerinin, yaş, cinsiyet ve eğitim değişkenleri açısından inceleniyor olmasıdır. Aynı zamanda araştırma bulguları, bireylerin iletişim becerilerinin geliştirilmesine yönelik eğitim programlarının gerekliliğini de ortaya koymaktadır. 


\title{
EXTENDED ABSTRACT
}

\section{An Investigation of Communication Skills of Elderly Individuals and Their Caregiver Relatives \\ *}

\author{
Seher Ersoy Quadir - Gülay Temiz \\ Necmettin Erbakan University - Selçuk University
}

Aging is the decrease in the productivity of the organism and the ability of the person to adapt to the environment as a result of biological losses (Akgün, 2012, p.51). Thus, the problem for the overwhelming majority of older people is related to the accumulation of mild disability and sensory losses, with reduced daily productivity and slowing of information processing (Rabbitt ve Carmichael, 1994, p.173). This situation causes losses in the daily life skills and communication levels of the elderly people; it can often result in the elderly withdrawing from social life. In such a situation, the communication style of the caregiver family member becomes a vital factor affecting the quality of life of the elderly individual.

The frequency of communication between elderly parents and their children, who often care for them, makes elderly people feel good. However, the quality of the relationships is more important than the quantity. Whether the relationship is based on love or is carried out with a sense of obligation determines the quality of the communication (İçli,2008, p.37). Therefore, proper and effective communication in elderly care is too important to be left to the conscience of caregivers. As a matter of fact, in the study conducted by Fried et al. (2004), it was determined that a large proportion of both seriously ill elderly $(66.7 \%)$ and caregivers $(83.1 \%)$ in the sample group included an unmet desire to increase communication.

It can be said in line with the above; A healthy communication as well as the emotional bond between the elderly person and his / her caregiver, undoubtedly increases the quality of life of both the elderly individual and the caregiving family member. Therefore, the purpose of this study is to measure the communication levels of the elderly person and his / her caregiver relatives and to determine the effect of demographic characteristics of both parties on their communication levels. 
Scanning model was used in the research. "Scanning models are research approaches that aim to describe a past or present situation as it exists. The event, individual or object subject to research is tried to be defined in its own conditions and as it is." (Karasar, 2012).

The population of the study was composed of elderly individuals aged 60 years and over residing in the districts of Karatay, Selçuklu and Meram, which formed the city center of Konya in 2017. The sample of the study consisted of 115 individuals selected by random sampling method from the elderly population and 115 relatives who took care of them.

In the study, the "Communication Skills Scale" developed by Balc1 (1996) and revised by Ersanlı and Balc1 (1998) was used to measure the communication skills of elderly individuals and their caregivers. As a result of the statistical analysis made in this study, it was found that the "Communication Skills Scale" has sufficient reliability (Alpha $=0.806$ ). Confirmatory factor analysis was also conducted to test the validity of the scale. According to the confirmatory factor analysis, the scale was not valid, and re-exploratory factor analysis was needed. As a result of the exploratory factor analysis, the number of items in the scale decreased from 45 to 42 . As a result of the analysis, two factors with eigenvalues of 1 and above were obtained. The first factor containing 25 statements was named as "Positive communication habits" and the second factor containing 17 negative statements was named as "Negative communication habits."

T-test in independent groups was used to compare the scores of elderly individuals and caregivers on the "Communication Skills Scale". In addition, the existence of a relationship between demographic characteristics of the sample group and communication skill scores was examined by calculating the Pearson Correlation Coefficient. One-way ANOVA test was applied to reveal the score difference between the sub-dimensions of the education level and social security variable, which are among the demographic features. In order to reveal the difference in points between sub-dimensions of the age variable, a t-test was conducted in independent groups.

When communication skill levels of elderly people and caregivers are compared; Although both groups have sufficient positive communication skills, it was observed that the total communication skills of the individuals who care for their elderly ( $\bar{X}=3.63$ ) are higher than the elderly individuals $(\bar{X}=3.41)$. This finding was statistically significant $(p<0.001)$ (Table 4$)$. 
In addition, communication skills of elderly people and caregivers were examined according to their demographic characteristics. It has been observed that, the younger ones ((59 years old and under: caregivers) had more communication skills than the older ones (60 years old and over: elderly people) $(\mathrm{r}=-0.229 ; \mathrm{p}<0.001)$. Women had more communication skills compared to men $(\mathrm{r}=-0.185 ; \mathrm{p}<0.01)$. Those with a high education level had more communication skills than those with a low level of education $(r=0.236 ; p<0.001)$. Finally, among the participants, it was determined that those who have civil servants' social security have higher communication skills than those who have workers' and self-employments' social security $(r=0.148 ; \mathrm{p}<0.05)$ (Table $5)$.

No significant relationship was found between communication skills of the sample group according to their marital status ( $p>0.05$ ), the number of their children ( $p>0.05)$, and their status of working in a paid job ( $p>0.05)$ (Table 5).

Decreases in sensory or brain functions with age negatively affect the communication skills of the elderly person. However, it would not be correct to explain the fact that communication skills of elderly individuals in the sample group are lower than the younger caregivers, with only sensory losses, although they have sufficient scores. Communication skill requires empathy, giving importance to the feelings of the other party, not being prejudiced and looking at events positively. It can be improved with life experience as well as with education. It should not be forgotten that although old generations have life experience, they cannot follow technology as easily as new generations and cannot obtain new information from the internet. Since they cannot adapt to the changes in the new generation by adhering to their traditions, they cannot be flexible in their thinking and sometimes act prejudiced. Therefore, as can be seen in the demographic characteristics of the sample group (Table 1 and Table 2), it can be predicted that the higher education level of caregivers (63.5\% has a secondary school or higher education) compared to elderly individuals (77.4\% primary school and less educated) explains this difference in communication skills.

In line with the findings obtained, it can be said that communication skills training should be supported throughout the country in order to increase the life satisfaction of the people and to improve their mental health. For this pur- 
pose, public education programs should be expanded in the short term in order to increase the awareness of individuals and to improve their communication skills. In this context, "Communication Skills Training" should be provided to the public in cooperation with Higher Education Institution, Ministry of Education and Municipalities. In addition, "Effective Communication Techniques Training" can be given mainly in the "Elderly Patient Care" curriculum. It should be remembered that communication is two-sided and onesided effort can often be ineffective. For this reason, in addition to the caregiver individual, elderly individuals who become dependent on the home and whose only entertainment is watching television should be educated about effective communication through public spots broadcast in media programs.

\section{Kaynakça / References}

Akgün, M. (2012). Hastanede Yatan Yaşlı Hastalarda İletişim Güçlükleri ve Sağllk Çalışanlarının Yaklaşımı. Hemşirelikte Eğitim ve Araş̧trma Dergisi, 9(2), 51-56.

Arslantaş, Y. (1998). Sinıf Yönetiminde Öğretmen Iletişim Becerilerine İlişkin Öğretmen ve Öğrenci Görüşleri. (Yayımlanmamış Yüksek Lisans Tezi). Abant İzzet Baysal Üniversitesi Sosyal Bilimler Enstitüsü, Bolu.

Balc, S. (1996). Danışma Becerileri Ĕ̆itiminin Üniversite Öğrencilerinin İletişim Becerisi Düzeyine Etkisi. (Yayımlanmamış Doktora Tezi). Ondokuz Mayıs Üniversitesi Sosyal Bilimler Enstitüsü, Samsun.

Baykara Pehlivan, K. (2005). Öğretmen Adaylarının İletişim Becerisi Algiları Üzerine Bir Çalışma. İlköğretim-Online, 4(2), 17-23. (http://ilkogretim-online.org.tr/index.php/io)

Bingöl, G. ve Demir, A. (2011). Amasya Sağlık Yüksekokulu Öğrencilerinin İletişim Becerileri. Göztepe Tip Dergisi, 26(4), 152-159. (http://sbgoztepehastanesi.gov.tr/goztepetipdergisi/)

Cankurtaran, M. (2013). Özbakım ve Beslenme. B. D. Özbabalık Adapınar (Ed.). Temel Bakm Hizmetleri içinde (s. 82-93). (1. bs.). Eskişehir: TC Anadolu Üniversitesi (No: 2892) Açıöğretim Fakültesi (No: 1849) Yayın.

Claramita, M. ve Majoor, G. (2006). Comparison of Communication Skills in Medical Residents With and Without Undergraduate Communication Skills Training as Provided by the Faculty of Medicine of

Gadjah Mada University. (t.y). Education for Health, 19(3), 308-320. (DOI: 10.1080/13576280600937887) 
Cooper, K. (1989). Sözsüz Illetişim, İnsan Yönetiminde Vǚut Dilini Nasıl Kullanırı?? (T. Yalkın, Çev.). İstanbul: İlgi Yayıncllk ve Ticaret LTD ŞTí.

Connolly, M., Thomas, J. M., Orford, J. A., Schofield, N., Whiteside, S., Morris, J. ve Heaven, C. (2014). The Impact of the SAGE \& THYME Foundation Level Workshop on Factors Influencing Communication Skills in Health Care Professionals. Journal of Continuing Education in the Health Professions, 34(1), 37-46. (DOI:10.1002/chp.21214)

Cüceloğlu, D. (1997). İçimizdeki Biz. (12. bs.). İstanbul: Sistem Yayıncllk.

Çetinkaya, Z. (2011). Türkçe Öğretmen Adaylarının İletişim Becerilerine İlişkin Görüşlerinin Belirlenmesi. Kastamonu Ĕ̆itim Dergisi, 19(2), 567-576.

Durukan, E. ve Maden, S. (2010). Türkçe Öğretmenlerinin İletişim Becerileri Üzerine Bir Araştırma. Sosyal Bilimler Araştırmalarn Dergisi, 1, 59-74.

Ergin, A. (2011). Sağ̆lk Hizmetlerinde İletişim. (1. bs.). Ankara: An Yayıncllk.

Erigüç, G. ve Eriş, H. (2013). Sağlık Hizmetleri Meslek Yüksekokulu Öğrencilerinin Iletişim Becerileri: Harran Üniversitesi Örneği. Elektronik Sosyal Bilimler Dergisi, 12(46), 232-254. (http://dergipark.ulakbim.gov.tr/hacettepesid/index)

Erigüç, G., Şener, T. ve Eriş, H. (2013). İletişim Becerilerinin Değerlendirilmesi: Bir Meslek Yüksekokulu Öğrencileri Örneği. Hacettepe Sağlık İdaresi Dergisi, 16(1), 4565.

Erözkan, A. (2005). Üniversite Öğrencilerinin İletişim Becerilerini Etkileyen Faktörler. M.Ü. Atatürk Eğitim Fakültesi Ĕ̆itim Bilimleri Dergisi, 22, 135-150.

Ersanll, K. ve Balc, S. (1998). İletişim Becerileri Envanterinin Geliştirilmesi: Geçerlik ve Güvenirlik Çalışması, Türk Psikolojik Damışma ve Rehberlik Dergisi, 10 (2), 7-12. (http://dergipark.ulakbim.gov.tr/tpdrd/article/view/1058000208)

Finset, A., Ekeberg, Q., Eide, H. ve Aspegren, K. (2003). Long Term Benefits of Communication Skills Training for Cancer Doctor. Psycho-Oncology, 12, 686-693. (DOI: 10.1002/pon.691)

Fried, T.R., Bradley, E.H., O'leary, J.R. ve Byers, A.L. (2004). Unmet Desire for CaregiverPatient Communication and Increased Caregiver Burden. Journal of the American Geriatrics Society, 53(1), 86-92. https://doi.org/10.1111/j.15325415.2005.53011.x

Gölönü, S. ve Karc, Y. (2010). İletişim Meslek Lisesi Öğrencilerinin İletişim Beceri Düzeylerinin İncelenmesi (Ankara İli Örneği). İletişim Kuram ve Araştırma Dergisi, 31, 123-140. (http://iletisimdergisi.gazi.edu.tr/)

Görmüş, A. Ş., Aydın, S. ve Ergin, G. (2013). İşletme Bölümü Öğrencilerinin İletişim Becerilerinin Cinsiyet Rolleri Bağlamında İncelenmesi. Sosyal Bilimler Dergisi, XV(1), 109-128. 
Gülbahçe, Ö. (2010). K. K. Eğitim Fakültesi Öğrencilerinin Iletişim Becerilerinin İncelenmesi. Atatürk Üniversitesi Beden Eğitimi ve Spor Bilimleri Dergisi (Atabesbd), 12(2), 12-22.

Güven, S. ve Yılmaz, E. (2013). Yaşlı İstismarı ve İhmali. VII Uluslararası Yaşlllk Kongresi. "Aktifve Sağlkklı Yaşlanma". 23-25 Mayıs, Karabük: Türkiye Diyanet Vakfı Yayın,(ISBN:978-605-87089-3-8);158-160.

Harvey, P. ve Ahmann, E. (2014). Validation: A Family-Centered Communication Skill. Pediatric Nursing, 40(3), May-June, 143-147. (https://www.ncbi.nlm.nih.gov/pubmed/25134229)

İçli, G. (2008). Yaşlılar ve Yetişkin Çocuklar. Yaşlı Sorunlar Araştırma Dergisi, (1), 29-38. (http://dergipark.ulakbim.gov.tr/yasad/article/view/5000115883)

Igbo, H. I. ve Ikpa, I. (2013). Effects of the Basic Training Programme on Intra-Personal Coping and Communication Skills of the Personnel of Nigeria Security and Civil Defence Corps Benue State Command. Ife PsychologIA, 21(2), September, 290-295. (https://journals.co.za/content/ifepsyc/21/2?page=2)

Karasar, N. (2012). Bilimsel Araștrma Yöntemi. Nobel Yayıncllk. Ankara.

Karatekin, K., Sönmez, Ö. F. ve Kuş, Z. (2012). Ilköğretim Öğrencilerinin Illetişim Becerilerinin ÇeşitliDeğişkenler Açısından İncelenmesi. Turkish Studies -International Periodical For The Languages, Literature and History of Turkish or Turkic, 7(3), 1695-1708.(http://dx.doi.org/10.7827/TurkishStudies.3765)

Koç, B., Terzi, Y. ve Gül. (2015). Üniversite Öğrencilerinin İletişim Becerileri ile Kişilerarası Problem Çözme Becerileri Arasındaki İlişki. Uluslararası Türkçe Edebiyat Kültür Eğitim Dergisi, 4(1), 369-390.

Koponen, J., Pyörälä, E. ve Isotalus, P. (2012). Comparing three experiential learning methods and their effect on medical students' attitudes to learning communication skills. Medical Teacher, 34 (3), 198-207. (DOI: 10.3109/0142159X.2012.642828)

Korkut, F. (1996). İetişim Becerilerini Değerlendirme Ölçeğinin Geliştirilmesi: Güvenirlik ve Geçerlik Çalışmaları. Psikolojik Damışma ve Rehberlik Dergisi, 2 (7), 18-23. (http://dergipark.ulakbim.gov.tr/tpdrd/article/view/1058000207)

Korkut, F. (2005). Yetişkinlere Yönelik İletişim Becerileri Eğitimi. Hacettepe Üniversitesi Eğitim Fakültesi Dergisi, 28, 143-149.

Maviş, İ. ve Özbabalık, D. (2006). Yaslılıkta Nörolojik Temelli İletişim Sorunları ve Dil ve Konuşma Terapisi. Sosyal Bilimler Dergisi, 2006 (1), 1-17.

Mehrabian, A. (1972). Nonverbal Communication. Piscataway, NJ, Aldine Transaction.

Milli Eğitim Bakanlığı (MEB) (2014). Yaşlı Bakım Hizmetlerinde Illetişim. Ankara: Hasta ve Yaşlı HizmetleriAlanı, Milli Eğitim Bakanlığı Yayını. 
Nacar, F. S. (2010). Sını Öğretmenlerinin İletişim ve Kişilerarası Problem Çözme Becerilerinin Incelenmesi.(Yayımlanmamış Yüksek Lisans Tezi). Çukurova Üniversitesi Sosyal Bilimler Enstitüsü, Adana.

Özerbaş, M. A., Bulut, M. ve Usta, E. (2007). Öğretmen Adaylarının Algıladıkları İletişim Becerisi Düzeylerinin İncelenmesi. Ahi Evran Üniversitesi Kırşehir Eğitim Fakültesi Dergisi, 8(1), 123-135.

Özşaker, M. (2013). Beden Eğitimi ve Spor Yüksekokulu Öğrencilerinin İletişim Becerileri ve Benlik Sayglarının Değerlendirilmesi. International Journal of New Trends in Arts, Sports and Science Education, 2(3), 29-39.

Powe, B.T. ve Lennie, S.C. (2012). Pre-registration dietetic students' attitudes to learning communication skills. Journal of Human Nutrition and Dietetics, 25, 189-197. (DOI: 10.1111/j.1365-277X.2012.01226.x)

Rabbitt, P.M.A. ve Carmichael, A. (1994). Designing communications and informationhandling systems for elderly and disabled users. J. Snel ve R. Cremer (Ed.). Work and Aging içinde (ss. 173-178). London: Taylor \& Francis Ltd.

Reed, V. A., McLeod, K. ve McAllister, L. (1999). Importance of Selected Communication Skills for Talking With Peers and Teachers: Adolescents' Opinions. Language, Speech, and Hearing Services in Schools, (30), 32-49.

Saracaloğlu, A. S., Yenice, N. ve Karasakaloğlu, N. (2009) Öğretmen Adaylarının İletişim ve Problem Çözme Becerileri İle Okuma İlgi ve Alışkanlıkları Arasındaki İlişki. Yüzüncü Yıl Üniversitesi Eğitim Fakültesi Dergisi, VI(II), 187-206.

Takahashi, M., Tanaka, K. ve Miyaoka, H. (2006). Reliability and validity of communication skills questionnaire (CSQ). Psychiatry and Clinical Neurosciences, 60, 211218. (doi/10.1111/j.1440-1819.2006.01488.x/pdf)

Thistle, J. J. ve McNaughton, D. (2015). Teaching Active Listening Skills to Pre-Service Speech-LanguagePathologists: A First Step in Supporting Collaboration With Parents of Young Children Who

Require AAC. Language, Speech, and Hearing Services in Schools, 46, 44-55. (DOI: 10.1044/2014_LSHSS-14-0001)

Toy, S. (2007). Mühendislik ve Hukuk Fakülteleri Öğrencilerinin İletişim Becerileri Açısından Karşılaştırılması ve İletişim Becerileriyle Bazı Değişkenler Arasındaki İişkiler. (Yayımlanmamış Yüksek Lisans Tezi) Ankara Üniversitesi Sosyal Bilimler Enstitüsü, Psikoloji (Sosyal Psikoloji) Anabilim Dalı, Ankara.

Tunçeli, H. İ. (2013). Öğretmen Adaylarının İletişim Becerileri ile Öğretmenlik Mesleğine Yönelik Tutumlanı

Arasındaki İlişkinin İncelenmesi (Sakarya Üniversitesi Örneği). Pegem Eğitim ve Öğretim Dergisi, 3(3), 51-58. (www.pegegog.net) 
Turan, S. (2014). Aile ve Yaşlanma. Y. Şişman (Ed.). Sosyal Sorunlar içinde (ss. 212-246). ( 1. bs.) Eskişehir: T.C. Anadolu Üniversitesi (No: 3129) Açıköğretim Fakültesi (No: 2038) Yayın.

Ulukan, H. (2012). Iletişim Becerilerinin Takım ve Bireysel Sporculara Olan Etkisi. (Yayımlanmamış Yüksek Lisans Tezi). Karamanoğlu Mehmetbey Üniversitesi Sosyal Bilimler Enstitüsü, Beden Eğitimi ve Spor Öğretmenliği Ana Bilim Dalı, Karaman.

Wang, M. V., Lekhal, R., Aarø, L. E. ve Schjølberg, S. (2012). Co-occurring development of early childhood communication and motor skills: results from a populationbased longitudinal study. Child: Care, Health and Development, 40 (1), 77-84. (DOI: $10.1111 /$ cch.12003)

Wilma, M.C.M., Caris-Verhallen, MSc RN., Ingrid M., De Gruijter, M.A., Kerkstra, A. ve Bensing, J.M. (2001). Factors related to nurse communication with elderly people. Leading Global Nursing Research, 30 (5), 47-58.

Yazıcıoğlu, Y. ve Erdoğan, S. (2004). Spss uygulamal bilimsel araşttrma yöntemleri. Ankara: Detay Yayınclık.Yıldırım Kaptanoğlu, A. (2012). Yaşlı Sağh̆ğı. İstanbul: TC Aile ve Sosyal Politikalar Bakanlığı Aile Eğitimi Programı Yayını.

\section{Kaynakça Bilgisi / Citation Information}

Ersoy Quadir, S. ve Temiz, G. (2021). Yaşlı bireylerin ve onlara bakım veren akrabalarının iletişim becerilerinin incelenmesi: Konya İli örneği. OPUS-Uluslararası Toplum Araştırmaları Dergisi, 17(38), 49584982. DOI: $10.26466 /$ opus. 713738 